\title{
The Analysis of Open Defecation Behaviour After Implementing the Tringger of Pillar 1 in Society Based Total Sanitation at Tulungagung Regency
}

\author{
Ida Ayu Anom Putrika ${ }^{1}$, \\ Indasah ${ }^{2}$, \\ Siti Farida Noor Laila ${ }^{2}$ \\ ${ }^{1}$ Magister of Health Study \\ Program of STIKes Surya Mitra \\ Husada Kediri \\ ${ }^{2}$ Lecturer of STIKes Surya Mitra \\ Husada Kediri \\ Email: \\ putrikadayu@gmail.com
}

Received : October 4, 2018

Accepted : October 6, 2018

Published : November 30, 2018

\begin{abstract}
Open defecation behavior is still practiced by some people who have obtained trigger pillar 1 society based total sanitation. The objective of the study is to analyze the factors that influence open defecation behavior after triggering implementation pillar 1 society based total sanitation. The research design used in this research is survey expansion. The population is the head of family with the behavior of open defecation that has obtained trigger pillar 1 in society-based total sanitation at Tulungagung regency. The sample size is 100 respondents by using Cluster sampling technique. Data were collected by using questionnaire, then the data were analyzed by using logistic regression. The results showed that a bad Open Defecation (57\%), low economic status (97\%), good knowledge $(100 \%)$, bad culture of defecate $(79 \%)$, good family support $(95 \%)$, less community support that is 58 respondents $(58 \%)$, good community leaders support $(100 \%)$, distance of house where chapter other than closet $(98 \%)$. Statistical test results in Overall Statistics with a significance value of (p) 0,000 which means that there are variables that affect the behavior of OD. When viewed the value (p) on each independent variable is economic status variables have a value (p) of 0,043 ; knowledge has value (p) of 1,000 ; attitude has a value (p) 0.383 ; cultural variables have value (p) 0,000; family support variables have (p) 0.046; the community support variable has (p) 0.004; support of community leaders have value (p) 0,125 and the distance of trowing feces place another of water closet variable has the value (p) 0,215. Open defecation behaviour after implementing the tringger of pilar 1 in Societybased total sanitation affected by factor cultur, community support, economic status and family support.
\end{abstract}

Keywords: Determines factors, society-based total sanitation, open defecation

Copyright (C) 2018 STIKes Surya Mitra Husada All right reserved.

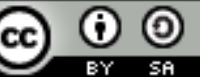

This is an open-acces article distributed under the terms of the Creative Commons Attribution-ShareAlike 4.0 International License.

\section{INTRODUCTION}

The Open Defecation (OD) Behavior (BABS) is one example of unhealthy behavior. BABS is an act of removing dirt or feces in fields, forests, shrubs, rivers, beaches or other open areas and allowed to spread contaminate the environment, soil, air and water (WHO, 2010).

According to WHO 2014, Open Defecation Behavior (BABS) becomes a critical global health issue affecting 1 billion people worldwide and contributes significantly to the deaths of 840,000 people annually due to poor sanitation and poor hygiene behavior (WSP 2016). 
Based on WHO data in 2015 estimated at 892 million people worldwide still defecate in open areas, 600 million people worldwide use limited sanitation services, 2.3 billion people worldwide are still lacking with one of the basic sanitation services (WHO, 2017).

The results of Riskesdas 2013 show that households in Indonesia use their own BAB facilities (76.2\%), joint ownership (6.7\%), and public facilities (4.2\%). Households that do not have BAB facilities so that BAB carelessly, that is equal to $12.9 \%$ (Ministry of Health RI, 2013).

A study by the Water and Sanitation Program (WSP) shows that Indonesia has lost approximately 6.3 billion USD (Rp 56.7 trillion) annually as a result of poor sanitation and hygiene conditions (equivalent to 2.3\% Gross Domestic Product/GDP) (MCA-Indonesian and Ministry of Health, 2015).

To improve sanitation condition, there will be integrated intervention through total sanitation approach. For that reason, the government changed the national sanitation development approach from the sectoral approach with the provision of hardware subsidy which has not leveraged the change of hygienic behavior and improved sanitation access, became the approach of Total Community Based Sanitation (STBM) which pressed on 5 (five) pillars changes in hygiene behavior (USDP, 2014).

STBM is an approach to change hygiene and sanitary behavior through community empowerment by triggering the way stipulated in government policy that is Regulation of Minister of Health of Republic of Indonesia No.3 Year 2014 about STBM.

There are five (5) pillars to be achieved in the STBM program where the first pillar (1) is Stop Misery. It is expected that by 2025, Indonesia can achieve total sanitation for the whole community, as stated in the Indonesian National Long Term Development Plan (KEPHR) 2014).

STBM is a participatory approach that invites the community to analyze their sanitary conditions through a triggering process, so that people can think and take action to abandon their habitual defecation. The approach taken in STBM attacks / creates a sense of horror and shame to the community about the condition of the environment. From this approach, awareness is also raised that sanitation is a common problem because it can have implications for all communities, so the solution must also be done and solved together (Ministry of Health RI, 2014).

Based on data from East Java Provincial Health Office, the achievement of STBM shows improvement in 2012 access to health latrines reach 68.8\%, in 2013 reaching 71.12\%, 2014 reached $72.4 \%$ and in 2015 reached $72.93 \%$.

Based on data from the District Health Office Tulungagung STBM implemented since 2008 in several subdistricts and villages. The results show an increase from year to year in 2012 access to a healthy latrine reached $50.8 \%$, in 2013 reached $52.76 \%$, in 2014 reached $54.57 \%$, in 2015 reached $91.58 \%$ and in 2016 reached 93,4\%. Until 2016, the number of villages that have received 1 pillar pillar STBM 192 villages from 271 villages in Tulungagung District. ODF villages have 107 villages (39.48\%) but there are $164(60.52 \%)$ villages that are still OD.

Implementation of the 1st pillar STBM program that has been implemented in Puskesmas is a meeting of STBM facilitators in the framework of activity planning, pillar 1 (Stop BABS) in communities and schools, post-trigger monitoring and evaluation, ODF verification and ODF Declaration.

The data of access progress of Tulunggung district by the end of 2016 shows the number of HHs that access permanent healthy latrines as much as 204,384 HH (58.5\%), the number of HHs with access to semi permanent healthy latrines is $86,518 \mathrm{KK}(21.9 \%)$, the number of KK sharing as many as 35,515 families (10.17\%) and the number of families who OD as much as 22,683 families $(6.49 \%)$. Of 22,683 families with OD behaviors that have got pillar 1 pillar trigger as many as 4532 families.

The target of the National Commitment is Universal Access 2015-2019 sanitation access is $100 \%$, while the number of villages in Tulungagung regency that has not ODF is $60.51 \%$ and the access achievement is $93.4 \%$ from 19 districts in Tulungagung Regency.

To attribute Unniversal Access to 6.6\% KK who still behave OD in Tulungagung District it is necessary to know the cause and reason why the behavior of OD is still practiced by some people who have obtained pemicuan pillar 1 STBM in Tulungagung regency. This study aims to analyze the factors that influence the behavior of open defecation post-implementation implementation of pillar trigger 1 STBM. 


\section{MATERIALS AND METHODS}

This study uses survey expansion format. The study was conducted in Tulungagung District. The study was conducted in December 2017, independent or independent variables in this study were Economic Status, Behavior, Culture, Family Support, Community Support, Community Promotion Support, Mileage Distance beside Puskesmas. Dependent variable or dependent variable in this research is Open Defecation behavior post pillar trigger 1 STBM. Population in this research is all head of family (KK) which still behave Open Defecation after triggering pillar 1 STBM in Tulungagung Regency at the time of research that is number 4,532 KK. Determination of the sample in this study is by Cluster sampling technique that determines the minimum sample size using Taro Yamane formula. From the sample of at least $\mathrm{n}(\mathrm{min})=98$ respondents. To be more representative then the number of samples added to 100 respondents. Random sampling. (Cluster Sampling), Tool used is questionnaire. Analysis using Logistic Regression Test with $\alpha=0,05$. And have passed the test of ethics.

\section{RESEARCH RESULT}

\section{Characteristics of the Subject}

Table 1. Characteristics of respondents in this study include age, gender, number of family members, education, employment, open defecation behavior, economic status, attitude, defecation culture, family support and distance to the place of defecation.

\begin{tabular}{|c|c|c|c|}
\hline No & Karakteristik & $\Sigma \mathbf{N}$ & $\Sigma \%$ \\
\hline \multirow{4}{*}{1} & Age (year) & & \\
\hline & $20-40$ & 46 & 46 \\
\hline & $41-60$ & 52 & 52 \\
\hline & $>60$ & 2 & 2 \\
\hline \multirow[t]{3}{*}{2} & Gender & & \\
\hline & Man & 70 & 70 \\
\hline & female & 30 & 30 \\
\hline \multirow[t]{4}{*}{3} & Education & & \\
\hline & Primary shcool & 32 & 32 \\
\hline & Junior high school & 32 & 32 \\
\hline & Senior high school & 36 & 36 \\
\hline \multirow[t]{4}{*}{4} & Number of family members & & \\
\hline & $1-5$ & 78 & 78 \\
\hline & $6-10$ & 15 & 15 \\
\hline & $>10$ & 1 & 1 \\
\hline \multirow[t]{5}{*}{5} & Work & & \\
\hline & laborers & 41 & 41 \\
\hline & Entepreneur & 27 & 27 \\
\hline & Farmers & 27 & 27 \\
\hline & Etc & 5 & 5 \\
\hline \multirow[t]{4}{*}{6} & Open defecation behavior & & \\
\hline & Not good & 57 & 57 \\
\hline & Good & 43 & 43 \\
\hline & Ekonomi status & & \\
\hline \multirow[t]{2}{*}{7} & Low & 97 & 97 \\
\hline & Medium & 3 & 3 \\
\hline \multirow{3}{*}{7} & Attitude & & \\
\hline & Good & 99 & 99 \\
\hline & Not good & 1 & 1 \\
\hline \multirow{3}{*}{8} & BAB culture & & \\
\hline & Bad culture & 79 & 79 \\
\hline & Good culture & 21 & 21 \\
\hline \multirow{3}{*}{9} & Family support & & \\
\hline & Minus & 5 & 5 \\
\hline & Good & 95 & 95 \\
\hline \multirow[t]{4}{*}{10} & Distance to the place of defecation & & \\
\hline & Nearby & 98 & 98 \\
\hline & Far & 2 & 2 \\
\hline & Total & 100 & 100 \\
\hline
\end{tabular}


Based on the table 1 above it is known that from the total of 100 respondents aged 41-60 years that is as many as 52 respondents (52\%), male sex that is as much as 70 respondents (70\%), has a family number $1-5$ souls that is 78 of respondents (78\%), high school education, 36 respondents (36\%), work as 41 respondents (41\%), have bad defect that is 57 respondents (57\%), have low economic status as many as 97 respondents (97\%), have a good attitude that is 99 respondents (99\%), have a bad culture of $\mathrm{BAB}$ which is 79 respondents (79\%), have good family support that is as much as 95 respondents (95\%) and has a distance to the place of defecation in addition to the nearby latrine as many as 98 respondents $(98 \%)$.

Table 2. Logistic Regression Test Analysis of Fitting Information Status Economics, Knowledge, Attitudes, Culture, Family Support, Community Support, Community Promotion Support and Distance Maintenance Stool besides Jamban with Open Defecation Behavior Post-implementation Pillar Introduction 1 Community-Based Total Sanitation at Tulungagung District $(n=100)$.

Model Fitting Information

\begin{tabular}{ccccc}
\hline Model & -2 Log Likelihood & Chi-Square & df & Sig. \\
\hline Intercept Only & 63,731 & & & \\
\hline Final & 9,806 & 53,925 & 6 &, 000 \\
\hline
\end{tabular}

Link function: Logit.

The result of statistical test using degrees of error 0.05 and obtained p value 0,000 , if the value of $\mathrm{p}$ value <degree of error, then $\mathrm{H} 1$ accepted or no influence, but if the value of $\mathrm{p}$ value> degree of error then $\mathrm{H} 0$ accepted or no significant effect. So the value of $\mathrm{p}$ value $<0,05$, then $\mathrm{H} 1$ accepted, meaning there is influence of economic factor, knowledge factor, attitude factor, cultural factor, family support factor, community support factor, support factor of public figure, latrines against Open Defecation behavior.

Pseudo R-Square

\begin{tabular}{cc}
\hline Cox and Snell &, 417 \\
\hline Nagelkerke &, 559 \\
\hline McFadden &, 395 \\
\hline
\end{tabular}

The result of the statistical test in this research is Pseudo R square value at Nagelkerke of 0,559. This means Economic Status, Knowledge, Attitude, Culture, Family Support, Community Support, Community Support and the distance of trowing feces place another of water closet other than Jamban in explaining Open Defecation behavior of 0,559 or $55.9 \%$ and there are $100 \%-55.9 \%=$ $44.1 \%$ other factors outside the model in implementing Open Defecation behavior. 
Variables in the Equation

\begin{tabular}{|c|c|c|c|c|c|c|c|}
\hline \multirow{2}{*}{\multicolumn{2}{|c|}{ Step 0 Constant }} & $\mathrm{B}$ & S.E. & Wald & $\mathrm{df}$ & Sig. & $\operatorname{Exp}(\mathrm{B})$ \\
\hline & &,- 282 & ,202 & 1,947 & 1 & ,163 &, 754 \\
\hline & & & & & Score & $\mathrm{df}$ & Sig. \\
\hline \multirow{9}{*}{ Step 0} & \multirow{9}{*}{ Variables } & Economic & & & 4,103 & 1 & ,043 \\
\hline & & Attitude & & & ,761 & 1 & ,383 \\
\hline & & Knowledg & & & ,567 & 1 & 1,000 \\
\hline & & Culture & & & 29,545 & 1 & ,000 \\
\hline & & $\overline{\text { Family su }}$ & & & 3,870 & 1 & 046 \\
\hline & & Comunity & & & 8,368 & 1 & 004 \\
\hline & & Support o & munity & & 5,553 & 1 &, 125 \\
\hline & & Distance & & & 1,570 & 1 & ,215 \\
\hline & & Overa & istics & & 42,633 & 8 & ,000 \\
\hline
\end{tabular}

The statistical test in this study used logistic regression test, as the test result is listed in the above table. The result of statistic test in this research shows that in vairables in the equation we get slope or Beta (B) coefficient of constant (Exp (B) of -0.2282 , p value of significance value of wald test of 0.163 , which means that each variable gives a partial influence $\mathrm{B}$ is identical to the beta coefficient in the ordinary least square (OLS) with $\operatorname{Exp}(0.282)=0.754$, which means the independent variable has a positive influence of $75.4 \%$ to the dependent variable The statistical test results obtained total df is 6 means the number of independent variables is 6 .

The next statistical test results in the second table shows that $\mathrm{p}>$ a with a value $<0.05$, it is seen in the Overall Statistics with a significance value of (p) 0.000 which means that there are variables that affect Open Defecation behavior. When viewed value (p) on each independent variable that is economic status variable has value (p) equal to 0,043 ; knowledge (p) 1,000; attitude has a value (p) 0.383; cultural variables have value (p) 0,000; family support variables have (p) 0.046; community support variables have (p) 0.004; variable of community figure support (p) 0,125 and variable of bowel movement distance beside toilet have value (p) 0,215 .

\section{DISCUSSION}

Based on the results of the research shows that most Respondents have the Distance of the house with the place of defecation beside the nearby toilet which is 98 responden (98\%). The result of the research shows that most of the respondents have the distance of defecation in addition to the latrine which is close to the bad behavior of Open Defecation by 55 respondents (55\%). The statistical test using Chi Square test obtained $\rho$-value $=0,003$ with $95 \%$ confidence level $(\alpha=0,05)$ means that there is influence of distance factor of defecation beside toilet to Open Defecation behavior. Distance traveled in this research is the distance of 1 meter to 100 meters is a close category and a distance of more than 100 meters is a distant category. The bowel place besides the latrine is the river which is where Open Defecation activity.

According to Notoatmodjo, 2011 states that the eccentric factors surrounding the physical environment mempe the formation of behavior. If the distance to the river for access to defecation is close then the public will tend to easily behave Open Defecation but if it is far then the public will feel to consider because during the trip Open Defender actors must withstand pain diutut especially when diarrhea illness.

The results of this study are similar to the results of Qudsiyah et al., 2013. The distance to the bowel box in addition to latrines in the adjacent category is 20.250 times greater than the high rate of Open Defecation behavior compared to the distance of the house to the toilet beside the toilet of the distant catagory. The behavior of a person or society about health is determined by various factors such as knowledge, attitude, habit, culture, availability of facility, health officer support, environmental factor and others. Environmental or geographical factors are very influential on health 
behavior where the closer the community with the river the greater the utilization of river water for household needs.

The results of this study indicate the behavior of Open Defecation done in the river because of geographical conditions in Tulungagung regency most of the watershed. Easily accessing the river for defecation causes Open Defecation behavior to be perpetuated by the community after the implementation of the pillar 1 STBM trigger. The need for latrines is still ruled out because there is a nearby river and surrounding communities also participate in the behavior of Open Defecation in the river so it is very convenient even as a means of socializing with neighbors. If there is a village law that prohibits the behavior of Open Defecation in the river and the public's agreement to impose sanctions to the actors of Open Defecation behavior in the river then the habits will soon be stopped because of feelings of shame breaking the village rules, the feeling of shame will arise desire to build latrines.

The result of statistic test of logistic regression in the second stage shows that $\mathrm{p}>$ a with value a $<0,05$, it is seen in Overall Statistics with significance value equal to (p) 0.000 which means that there are variables that influence Open Defecation behavior. When viewed value (p) on each independent variable that is economic status variable has value (p) equal to 0,043 ; knowledge (p) 1,000; attitude has a value (p) 0.383 ; cultural variables have value (p) 0,000; family support variables have (p) 0.046; community support variables have (p) 0.004; variables support community leaders (p) 0.125 and variable mileage where the distance of trowing feces place another of water closet other than the toilet has a value (p) 0.215 . Thus the most influential independent variables are cultural factors, community support, economic status and family support.

The concept of STBM is the result of the adoption of Community Led Total Sanitation (CLTS) is a rural sanitation development approach with the Principles of STBM that is Without Subsidy, Community as Leader, Not Patronizing or Forcing, and Totality. In accordance with Nugraha (2015) research results in Lumajang stated that the STBM program brings some positive changes that make people better in various fields such as environment, social, health and culture. Communities have many benefits for their survival, especially in the use of latrines.

Open Defecation Free (ODF) is a condition when every individual in the comminity does not defecate carelessly. The ultimate goal of STBM pillar initiation is the realization of ODF Village with indicator that all people defecate only in healthy latrines and dispose of baby faeces only into healthy latrines (including at school), no visible faeces/faeces in the environment around.

In this study, the most influential factors on the behavior of cultural factors, community support, economic status and family support can facilitate the strategy of behavioral defecation in communities that still behave in Open Defecation after the implementation of triggering pillars 1 STBM, among others by government regulation villages to prohibit defecation behavior in the river, there is the application of sanctions, there is a general monitoring mechanism made by the community to reach $100 \%$ of families have healthy latrines, formed a group of arisan latrines, intensify the culture of gotong royong to build latrines for poor families with triggers in middle economic community up and stimulant of latrine through the village fund and the enforcement of village regulations in order to be interested in the behavior of defecation so as not to cause health problems in the community.

\section{CONCLUSION}

Factors Economic Status, Knowledge, Attitudes, Culture, Family Support, Community Support, Community Support and the distance of trowing feces place another of water closet Beside Jamban Together Affects Behavior Open Defecation Post Implementation Pillar 1 STBM with logistic regression test that is statistical test result Overall Statistics with a significance value of (p) 0,000 which means that there are variables affecting Open Defecation behavior. When viewed value (p) on each independent variable that is economic status variable has value (p) equal to 0,043 ; the knowledge variable has a value (p) 1,000; attitude variable has value (p) 0,383; cultural variables have value (p) 0,000; family support variables have (p) 0.046; community support variables have (p) 0.004; the support variable of public figure has (p) 0.125 and the distance variable where defecation beside latrine has value (p) 0,215. The result of statistical test of Pseudo R square on Nagelkerke obtained value of 0,559 this means dependent variable factor in explaining Open Defecation behavior of 0,559 
or $55,9 \%$ and there are $100 \%-55,9 \%=44,1 \%$ other factor outside model in the implementation of Open Defecation behavior.

\section{BIBLIOGRAPHY}

Badan Penelitian dan Pengembangan Kesehatan Kemenker RI. (2013). Riset Kesehatan Dasar 2013, Jakarta.

Badan Pusat Statistik Kabupaten Tulungagung. (2016). Statistik Daerah Kabupaten Tulungagung, Tulungagung.

Bart, Smet. (1994). Psikologi Kesehatan. PT. Gramedia Widiasarana Indonesia. Jakarta.

Cintya, C. V. D. (2016). Hubungan Pengetahuan Masyarakat Tentang Program ODF (Open Defecation Free) dengan Perilaku Buang Air Besar Sembarangan, Jurnal Keperawatan dan Kebidanan, 57-61.

Darsana, I. N., Mahayana, I. M. B. \& Patra, I. M. (2014). Faktor-Faktor yang Berhubungan dengan Kepemilikan Jamban Keluarga di Desa Jehem Kecamatan Tembuku Kabupaten Bangli, Jurnal Kesehatan Lingkungan, 4 : $124-133$.

Friedman, (2005). Keperawatan Keluarga. Yogyakarta: Gosyen Publishing.

Indrayani, Y., Yuniarti., \& Latif, Rr. V. N. (2016). Kajian Strategi Fromosi Kesehatan Sanitasi Total Berbasis Masyarakat (STBM) Kelurahan Tirto Kota Pekalongan, Unnes Journal of Public Helth, UJPH 5 (3) (2016), http//journal.unnes.ac.id/sju/index.php/ujph.

Kail, Cavanaugh. (2000). Human-Development: A Life-Span View.

Kementrian Kesehatan. (2014). Peraturan Menteri Kesehatan Republik Indonesia, Nomor 3 Tahun 2014 tentang Sanitasi Total Berbasis Masyarakat, Jakarta.

Kementrian Kesehatan. (2014). Kurikulum dan Modul Pelatihan untuk Pelatih (TOT) Fasilitator STBM di Indonesia, Jakarta.

MCA-Indonesia, Kementrian Kesehatan. (2015). Pedoman Pelaksanaan Sanitasi Total Berbasis Masyarakat Proyek Kesehatan dan Gizi Berbasis Masyarakat, Jakarta.

Mulyanto, Sumard. (2005). Sumber Pendapatan Kebutuhan Pokok dan Perilaku Menyimpang. CV. Rajawali. Jakarta.

Nugraha, M. F. (2015). Dampak Progran Sanitasi Berbasis Masyarakat (STBM) Pilar Pertama di Desa Gucialit Kecamatan Lumajang, Kebijakan dan Menejemen Pubik ISSN-2303 - 341x, 3: 44 - 53.

Notoatmodjo, S. (2011). Kesehatan Masyarakat Ilmu \& Seni, Rineka Cipta, Jakarta.

Pane, E. (2009). Pengaruh Perilaku Keluarga Terhadap Penggunaan Jamban, Jurnal Kesehatan Masyarakat Nasional, 3: 229 - 234 .

Priyoto. (2014). Teori Sikap dan Perilaku dalam Kesehatan, Nuha Medika, Yogyakarta.

Qudsiyah, W. A., Pujiati, R. S. \& Ningrum, P. T. (2014). Faktor-faktor yang Berhubungan dengan Tingginya Angka Open Defecation (OD) di Kabupaten Jember, e Journal Pustaka Kesehatan, 3: 362-369.

Ratna, W. (2010). Sosiologi dan Antropologi Kesehatan dalam Persepektif Ilmu Keperawatan, Pustaka Rihama, Yogyakarta.

Riduan \& Akdon. (2010). Rumusdan Data dalam Analisis Statistika, Alfabeta, Bandung.

Rubbins, Stephen. P. \& Mary, Coulter. (2007). Manajemen. PT INDEKS. Kelompok Gramedia. Jakarta. 
The Analysis of Open Defecation Behaviour.....

Sugiyono. (2010). Metode Penelitian Pendidikan Pendekatan Kuantitatif, Kualitatif dan R\&D, Alfabeta, Bandung.

Wangmuba. (2009). Kecemasan dan Psikologi. Retreved april 13, 2009. From http://wangmuba.com/tag/kecemasan.

WHO/UNICEF. (2017). Progress on Drinking -Water, Sanitation and Hygiene 2017 Update and SDG Baselines, Denmark: ISBN 978-92-4-151289-3.

WORD BANK GROUP/WSP. (2016). Nudging and Habit Change for Open Defecation: New Tractics from Behavioral Science, University of Southern California. 